\title{
Utilization of Multimedia in Student News Video Projects on Praktik Jurnalistik Media Televisi Course
}

\author{
Titiek Fujita Yusandra ${ }^{1)}$, Welsi Haslina ${ }^{2)}$ \\ ${ }^{1)}$ Universitas PGRI Sumatera Barat, ${ }^{2}$ Politeknik Negeri Padang \\ email: titiekfujitayusandra86@gmail.com², welsih@yahoo.com ${ }^{2}$
}

\begin{abstract}
This article aims to explain the use of multimedia in the form of the kinemaster application in the learning process of making news videos in the Praktik Jurnalistik Media Televisi course. The method used is a descriptive method with a qualitative approach. Data were collected from field findings, participant data, and researcher reflections. Sources of data obtained from direct experience, the results of interviews, observations, and documentation from lecturers who are in charge of the Praktik Jurnalistik Media Televisi course at the Indonesian Language and Literature Education Study Program, STKIP PGRI Sumatera Barat. Based on the findings, the kinemaster application helps students in producing news videos. After the data, news scripts, and voices that have been recorded are complete, they take advantage of this application to combine video, sound and images. This application provides a fairly complete video editing feature and can directly edit it on the spot without having to move to another application. Thus, the use of learning resources in the form of multimedia applications in the Praktik Jurnalistik Media Televisi will increase the effectiveness of learning, so that learning becomes more meaningful for students to get direct experience in the use of technology.
\end{abstract}

Keywords: utilization, multimedia, news video project

\section{Introduction}

Learning in the 21st century, integrates literacy skills, knowledge skills, skills and attitudes, and mastery of technology. Technology and information media in recent years have made significant progress, so 21 st century learning is expected to be able to prepare its generation to be literate with rapidly developing technological and information advances. According to North Central Regional Educational Laboratory (NCREL) and Metiri Group (2003), 21st century technology and skills are intrinsically linked in learning requires the use of technology that supports mastery of 21st century skills. So that by maximizing the use of technology for the learning process, students can improve 21 st century skills (Khoirunnisa \& Habibah, 2020). These technological developments affect various aspects of life, including the learning process.

Multimedia learning is a component that can be used to support the learning process. Multimedia according to Philip (1997) are: "The multimedia component is characterized by the presence of text, pictures, sound, animation, and video; some or all of which are organized into some coherent program". Multimedia is a combination of text, images, sound, animation, and video; some of these components or all of them are incorporated into a coherent program. The use of multimedia in learning, especially the use of the kinemaster application, can motivate and increase the creativity of students in producing news video projects, so that they can support the learning process and improve the expected learning outcomes. Learning resources relate to everything in digital format that can be utilized by teachers and students for 
learning purposes. As humans and digital change lives, including innovation in the learning process (Rosida, 2021).

The Indonesian Language and Literature Education Study Program STKIP PGRI Sumatera Barat has three supporting profiles for graduates, namely being a teacher, teaching BIPA, as well as television and print media journalists. With the expansion of current job prospects, the Study Program strives for graduates to have credibility, intelligence, and skills that can compete in the world of work. Knowledge and skills alone are considered not optimal, it takes practice that supports the lecture process, especially to fulfill the profile of graduates of the Indonesian Language and Literature Education Study Program in the field of Journalism which is still considered narrow. As a follow-up, the Indonesian Language and Literature Education Study Program held a policy regarding practice in television media journalism courses, which aims to enable students to go directly to the field, search for news, collect data from various sources, record audio and video news scripts that have been made, to carry out the process. video editing. Martono (2020) explained that journalism is a new job for Indonesian language and literature students. Students have the opportunity to become journalists. Graduates of the Indonesian Language and Literature Education Study Program can work in the world of newspapers (print and online) and television.

Based on the results of observations made on television media journalism students, most of them have difficulty covering news in the field which is an important aspect as a provision for practice in the field. Judging from the previous year, the journalism practice course on television media still focuses on news scripts written by students based on the data they get from the field. The development of the times requires students to actively use technology, not only centered as news writers, but how to package the news by utilizing multimedia in the form of the kinemaster application.

To deal with the problems of student journalism skills, it is necessary to use the kinemaster application as a medium that can assist students in producing news video projects that are ready to be shared on social media pages. Kinemaster was chosen as news processing media because this application according to students is easy to use. The file size is quite light, only $25 \mathrm{MB}$, and its performance as long as I use it on the Redmia 5A smartphone, feels easy (Feinberg, Song, \& Lim, 2016). Kinemaster is a mobile application that is specifically designed to help Android and iOS users in modifying videos, from ordinary videos to more interesting videos. This application makes it easy for users to edit videos with all the tools provided in the display menu. With just a few touches, combining themes, animations, and effects can produce a masterpiece like a professional video editor.

One application that is good enough to process video-based information is kinemaster android, which can process text, process images, process videos and process animations so that they can be combined into an object that has knowledge value. The Kinemaster application has been widely used for convenience for the community, such as in research (Haryudin \& Imanullah, 2021) use kinemaster to create multimedia-based teaching materials, (Costaner, et al., 2021) skills training for making Digital Video-based information at the Mosque Youth Association, (Amelia, 2021) Development of Kinemaster Application-Based Learning Media on Integrated Thematic Learning in Grade III Elementary School, (Nurlaila, 2021) using the kinemaster application and google forms to improve PAI learning outcomes at SMAN 1 Kelayang, (Handoko, 2021) Utilization of kinemaster as a video ad creation application for PKBM managers and educators, (Khaira, 2021) the use of the kinemaster application as an ICT-based learning medium.

Journalism learning using multimedia in the form of the kinemaster application is expected to give a role to students' journalistic skills in terms of using technology to make it easier for students to disseminate the information they have created. Based on the description above, this article will explain the use of the kinemaster application by students in the practice of television media journalism. 


\section{Methods}

This article was conducted using a descriptive method with a qualitative approach and literature study. Qualitative research method is a naturalistic research method because the research is carried out in natural conditions (reality) as a whole. According to Bogdan and Taylor (in Moleong, 2011), qualitative research is a research procedure that produces descriptive data in the form of written and spoken words from people and observable behavior. This approach is considered relevant to describe the current conditions and becomes the background of the research, namely the use of multimedia in student news video projects.

Data were collected from field findings, participant data, and researcher reflections. Sources of data were obtained from direct experience, interviews, observations, and documentation from students and lecturers who teach elective courses in Television Media Journalism Practice at the Indonesian Language and Literature Education Study Program STKIP PGRI Sumatera Barat. In this study, the researcher went directly to the object as an instrument as well as data collection as well as a full participant observer to obtain information regarding the Utilization of Multimedia in the Student News Video Project.

\section{Results and Discussion}

The research results discussed in this section are the results of research on Multimedia Utilization in Student News Video Projects. The multimedia used by students is the kinemaster application to produce news video projects assigned to students. The journalistic work process begins with a planning process in the form of coverage plans, news angels to be covered, pictures/videos to be taken from the field, to news sources to be interviewed. After the planning stage is discussed, the next stage is to go to the field to cover the news, collecting data from various sources involved in the news being covered. The next process is to process the data obtained from the field into a news script with television news format. Then the news script will be recorded by the reporter/student and the last process is to combine audio and video using technology in the form of a kinemaster application.

Before using this application, students have prepared materials and data that will be included in the application. If the data has been saved in the cellphone folder, then the editing process through the kinemaster application can be carried out. The data and materials prepared by students to produce news videos are 1) opening video / initial tune, 2) video recording of reading news for the news terrace, 3) video input or pictures of events that they have recorded in the field, 4) voice recording for news body parts, 5) news cover recording.

The following will show the use of multimedia in the form of the Kinemaster application by students in producing news video projects in the Praktik Jurnalistik Media Televisi course. This kinemaster application is used for the editing process to combine audio and video that they have made before.
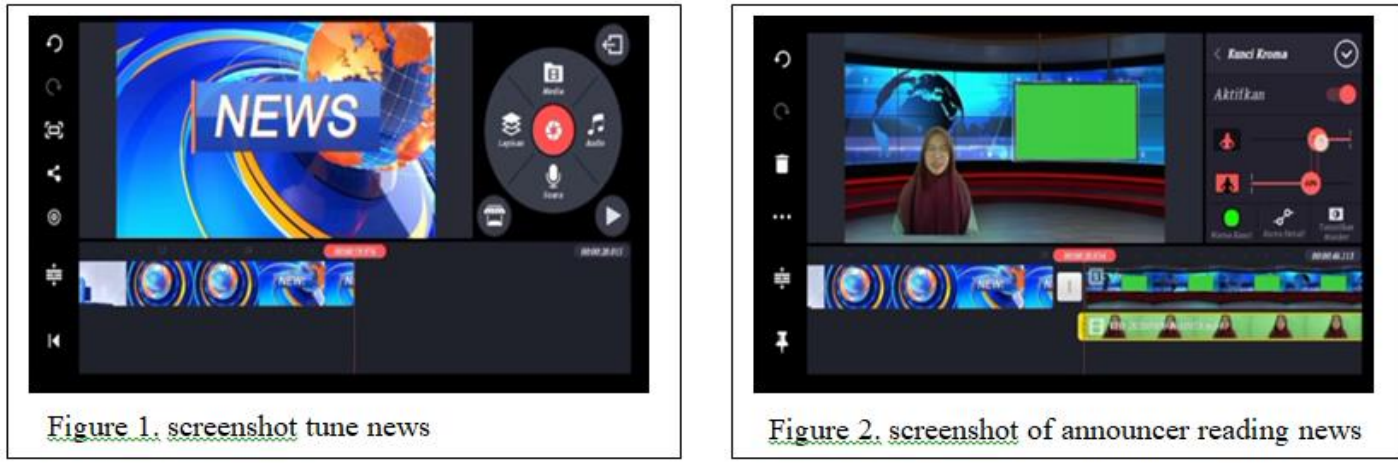

Figure 1 is a display of the recorded tune or news opening. This display serves as the identity of the information before entering the content of the news. In Figure 2, data is entered for broadcasters' video 
recordings of opening and reading news. The manuscripts that students read are on the news terraces that have been previously recorded. This application provides various types of overlays, transition effects, animations, backgrounds, additional fonts, music, and even allows users to change the background (chroma key) to make the resulting video look more attractive.
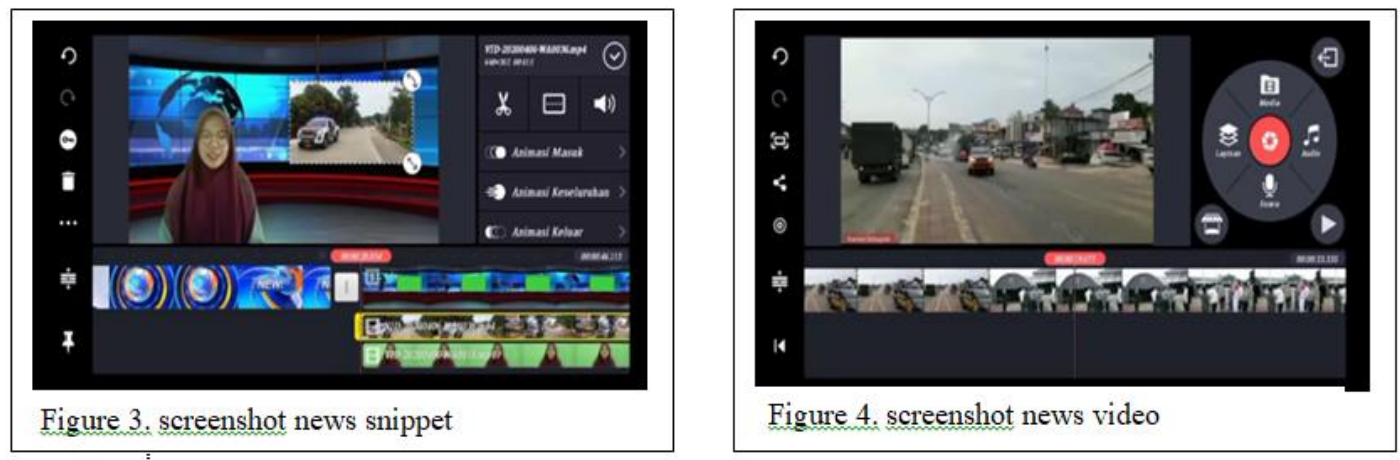

Figure 3. The process of adding a background to the main screen. When the announcer reads the news, a snippet of events will appear behind the announcer so that it adds to the synchronization of news content and video events obtained from the field. Figure 4 is the result of a video recording of events or body parts of the news which will later be added to the recording of the news script. In this case, it is necessary to match the news script with the images that will appear in the news video project.

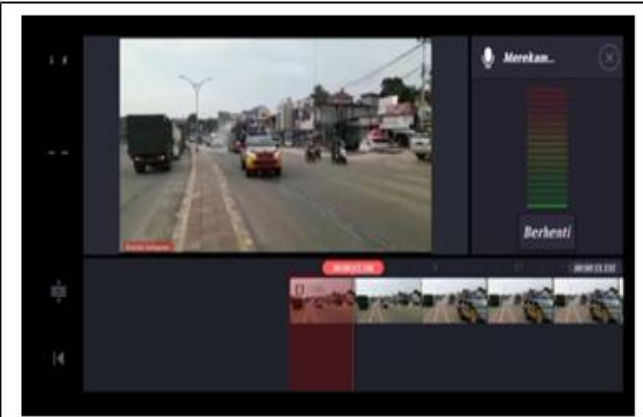

Figure 5 , screenshot of news script recording



Figure 6. screenshot news headline writing - 욜 $(\mathrm{Ctrl})$ r

Figure 5. is the process of recording the news script/audio body of the news to complete the video/picture of the events in the news. The process of recording the sound can be done directly on this application, making it easier for the news editing process. In this application, not only combines video, sound and images, this application can also directly edit them in place without having to move to another application. KineMaster also has a multitrack timeline to support all audio and visual components and control them directly. Furthermore, in Figure 6. Is the process of adding a title or headline that will appear on the video screen later. In this process, the size, type, and color of the text can be adjusted by yourself. 


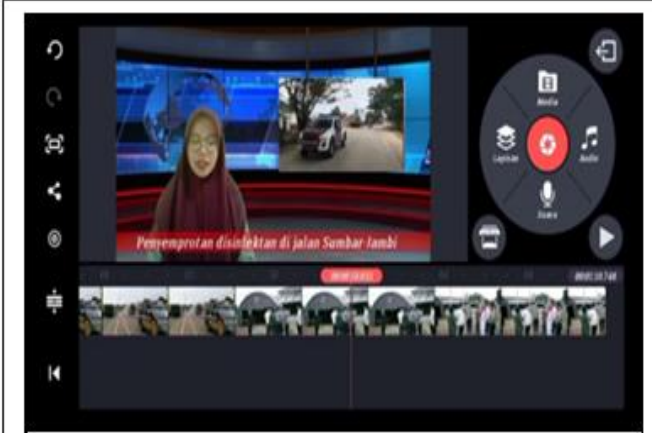

Figure 7. screenshot of headline on screen



Figure 8. screenshot news cover video

In Figure 7 the news title has appeared on the screen. The appearance of the headline / news title is important to clarify the information conveyed in the news. After all stages of news content have been entered into the application, the last editing process is to include a video closing news (Figure 8).
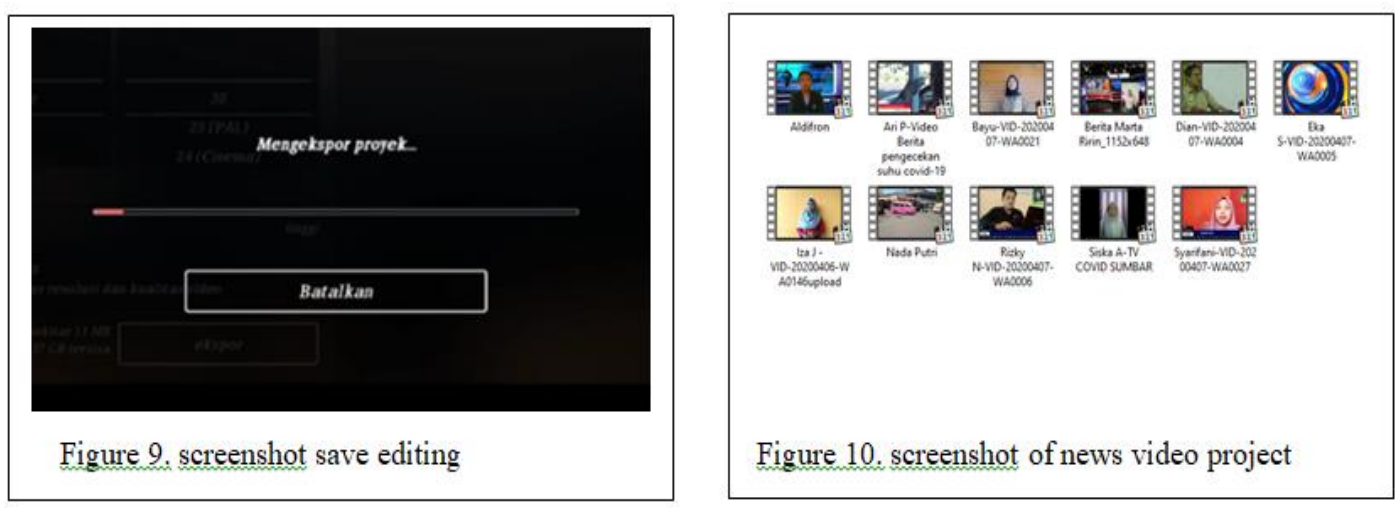

The last stage of the process of using the kinemaster application to produce a student news video project is to export the project or save the video editing that has been done (Figure 9). The process of exporting this project does not take long, approximately 1 minute of video editing and the news is ready to be distributed (Figure 10). In Figure 10 are some of the results of the news video project of students of the Indonesian Language and Literature Education Study Program STKIP PGRI Sumatera Barat which can be distributed through social media such as Whatsapp, Facebook, Youtube, and other social media.

Based on the image above, it can be seen that the process of using information technology by students in producing news video projects. The use of the kinemaster application aims to make it easier for students to process news and broadcast news. In this application, users can process information, process news editing, and publish news on social media pages. Digital era journalism always supports innovative expansion, has a creative paradigm to shape skills. The development of the times requires students to actively use technology, not only centered as news writers but also honing their skills to produce news video projects based on news scripts made.

\section{Conclusion}

Based on the news video project produced by students in the Television Media Journalism Practice course, students have been able to hone their skills in using technology to support the journalistic learning process. Where the main focus in this course is not only producing news scripts, but in the form of audio- 
visual news packages that can be published through social media. In making news video projects using the kinemaster application, careful preparation is needed so that video editing runs effectively and efficiently. The following are the stages of preparation for video editing; 1) prepare news material for which the video will be made, make sure the purpose and theme are clear. 2) Writing news scripts and interesting news titles. This will make it easier when shooting video. 3) Make original videos. Can use a green screen background that serves to change the background of the video. 4) Prepare supporting properties in the video. 5) Create an attractive Title. 6) Open kinemaster and do video editing.

\section{Acknowledgments}

The writer would like to thank Allah SWT, who has bestowed His mercy and grace, so that the writer can finish this article. Thank you also to all leaders and the Academic Community of Universitas PGRI Sumatera Barat, especially the Indonesian Language and Literature Education Study Program for trusting the author to teach the Television Media Journalism Practice course. Thank you to the committee of the International Conferences of Language Pedagogy (ICOLP) for selecting and accepting this article as part of the publication.

\section{References}

Amelia, V. (2021). Jurnal Inovasi Pendidikan dan Pembelajaran Sekolah Dasar Pengembangan Media Pembelajaran Berbasis Aplikasi Kinemaster Pada Pembelajaran Tematik Terpadu di Kelas III Sekolah Dasar. Jurnal Inovasi Pendidikan Dan Pembelajaran Sekolah Dasar, 4, 88-97.

Costaner. (2021). Pelatihan Keterampilan Membuat Informasi Berbasis Video Digital Pada Ikatan Remaja Masjid. Dinamisia: Jurnal Pengabdian Kepada Masyarakat, 5(4), 843-849. https://doi.org/10.31849/dinamisia.v5i4.7253.

Feinberg, M. A., Song, K. B., \& Lim, I. T. (2016). KineMaster - Pro video editing on android. ACM SIGGRAPH 2016 Appy Hour, SIGGRAPH 2016. https://doi.org/10.1145/2936744.2956677.

Handoko, A. (2021). Pemanfaatan Kinemaster sebagai Aplikasi Pembuatan Iklan Video Bagi Pengelola dan Pendidik PKBM. Jurnal Desain: Kajian Bidang Penelitian Desain, 1(1), 14-24. Retrieved from https://ejournal.lppm-unbaja.ac.id/index.php/abdikarya/article/download/1260/789.

Haryudin, A., \& Imanullah, F. (2021). the Utilization of Kinemaster Applications in the Making of Multimedia Based Teaching Materials for English E-Learning in New Normal (Covid-19). PROJECT (Professional Journal of English Education), 4(2), 341. https://doi.org/10.22460/project.v4i2.p341-352.

Khaira, H. (2021). Pemanfaatan Aplikasi Kinemaster Sebagai Media Pembelajaran Berbasis ICT. Prosiding Seminar Nasional Pembelajaran Bahasa ..., 39-44. Retrieved from http://digilib.unimed.ac.id/id/eprint/41218.

Khoirunnisa, E., \& Habibah, E. (2020). Profil Keterampilan Abad 21 (21st Century Soft Skills) Pada Mahasiswa. Iktisyaf: Jurnal Ilmu Dakwah Dan Tasawuf, 2(2), 55-68. https://doi.org/10.53401/iktsf.v2i2.20.

Martono. (2020). Pontianak Pos, Borneo Tribun, Tribun Pontianak, Equator, Metro, Berkat, Media Kalbar, Kapuas Pos, Mediator. 
Moleong, L.J. (2011). Metodologi Penelitian Kualitatif Edisi Revisi. Bandung: PT. Remaja Rosdakarya.

Nurlaila. (2021). Pemanfaatan Aplikasi Kinemaster dan Google Formulir dalam Meningkatkan Hasil Belajar PAI di SMAN 1 Kelayang. Pendidikan Tambusai, 5, 5941-5947.

Philips, R. (1997). A Practical Guide for Educational Applications. (London: Kogan Page Limited), h. 8.

Rosida, S. (2021). Efektivitas Media BIGVU pada Pembelajaran Jurnalistik dalam Meningkatkan Keterampilan Newscaster Mahasiswa PBSI. Jurnal Kiprah, 9(1), 48-55. https://doi.org/10.31629/kiprah.v9i1.3237. 